\title{
MAX WEBER, KAPİTALİZM VE İSLAM
}

\section{İsmail DEMİREZEN*}

Atıf/O: Demirezen, İsmail (2017). Max Weber, Kapitalizm ve İslam, Hitit Üniversitesi Sosyal Bilimler Enstitüsü Dergisi, Yıl 10, Sayı 1, Haziran 2017, ss. 1-14

Özet: Weber'in İslam hakkındaki yorumlarını anlamaya çalıştığımız bu makale beş bölümden oluşmaktadır. İlk olarak, modern kapitalizmin ortaya çıkışı ile İslam toplumları hakkindaki tezine bir zemin oluşturabilmek için, O'nun erken dönem İslam yorumları açıklanacaktır. İkinci olarak, İslam inançlarınn modern kapitalizmin gelişmesini engelleyip engellemediğini anlayabilmek için modern kapitalizmin ortaya çıkışı ile protestan ahlakı ilişsisi hakkındaki tezi açıklanacaktır. Üçüncü olarak, İslam dünyasında modern kapitalizmin gelişmesini İslami patrimonyalizmin engellediği iddiası tartışlacaktır. Dördüncü olarak, Weber'in İslam şehirlerinin, modern kapitalizmin Müslüman ülkelerde gelişmesinin engellenmesinde etkili olduğu düşüncesi incelenecektir. Son olarak, İslam hukukunun modern kapitalizmin gelişemesini engelleyip engellemediği hakkındaki iddialar ele alınacaktır.

Anahtar Kelimeler: Max Weber, Islam, Kapitalizm, Protestan Ahlakl.

\section{Max Weber, Capitalism and Islam}

Citation/O: Demirezen, İsmail (2017). Max Weber, Capitalism and Islam, Hitit University Journal of Social Sciences Institute, Year 10, Issue 1, June 2017, pp. 1-14

Abstract: As we are concerned with prompting an understanding of Weber's commentary on Islam, our remarks will fall under five headings. First, there is to be clarified Weber's commentary on early Islam to ground the discussion of his thesis about Islamic societies and the rise of modern capitalism. Secondly, there is to be examined his thesis about the relevance of the protestant ethics on the emergence of modern capitalism in order to understand whether or not Islamic beliefs impeded the development of modern capitalism. Thirdly, there are discussions that arise from Weber's claim that Islamic patrimonialism impeded the rise of modern capitalism in Islamic societies. Fourthly, we will notice Weber's discussions about Islamic cities' important effects on the hindrance of modern capitalism in Muslim societies. Finally, this paper will evaluate Weber's thesis on whether or not Islamic law impeded the rise of modern capitalism.

Keywords: Max Weber, Islam, Capitalism, Protestant Ethic.

\footnotetext{
Makale Geliş Tarihi: 29. 03. 2017/ Makale Kabul Tarihi: 23.05.2017

* Doç. Dr., İstanbul Üniversitesi, İlahiyat Fakültesi, Felsefe ve Din Bilimleri Bölümü, e-posta: idemirezen@hotmail.com
} 


\section{INTRODUCTION}

Max Weber (1864-1920) is best known for his study of protestant ethics and the spirit of modern capitalism. In that study, Weber claimed that Calvinism helped modern capitalism to rise. To strengthen his claim, he looked at other major world religions. From this perspective, he also took up Islam, which is one of the six major religions that he was mostly interested in (Schluchter, 1999, 53). He was interested in early Islam and its important features. In this attempt, Weber presented important commentaries on Islam. With his studies on Islam, he met the needs of systematic studies of Islam (Turner, 1974, 7). This situation makes the examination of Weber's commentary on Islam an important research priority.

The present study is offered in the conviction that it is important to explain Weber's commentary on Islam. While Weber presented important commentaries on religions, his interpretation of Islam enables the reader to test Weber's thesis about religion and society, especially capitalism. Thus, I am going to focus on his interpretation of Islam. In this attempt, it is necessary to address these questions: What were Weber's theses about the relationship between Islam and social institutions, especially the emergence and insistence of capitalist institutions?

As we are concerned with prompting an understanding of Weber's commentary on Islam, our remarks will fall under five headings. First, there is to be clarified Weber's commentary on early Islam to ground the discussion of his thesis about Islamic societies and the rise of modern capitalism. Secondly, there is to be examined his thesis about the relevance of the protestant ethics on the emergence of modern capitalism in order to understand whether or not Islamic beliefs impeded the development of modern capitalism. Thirdly, there are discussions that arise from Weber's claim that Islamic patrimonialism impeded the rise of modern capitalism in Islamic societies. Fourthly, we will notice Weber's discussions about Islamic cities' important effects on the hindrance of rational capitalism in Muslim societies. Finally, this paper will evaluate Weber's thesis on whether or not Islamic law impeded the rise of modern capitalism.

\section{THE ORIGIN OF ISLAM}

Before attempting to focus on the larger developmental issues which are at the center of Weber's comparative focus on the relationship between Islamic 
society and modern capitalism, it is useful to briefly discuss Weber's commentary on some essential features of early Islam and Weber's methodology on which it stands. By examining the rise of Islam, chapter two tries to focus on illustrating the importance of Weber's methodology in sociology and his failure in applying to the principles of his methodology as he was evaluating early Islam. Thus, the chapter not only explains the features of early Islam to ground the discussion of Weber's thesis about the relationship between Islam and capitalism, but presents Weber's methodology on which it stands as well.

Before considering his commentary on the origin of Islam, it is necessary to notice the foundation to which he claimed to adhere. Weber emphasized that social actions could be explained from subjective meanings which actors attached to their actions. He offers a type of understanding that makes an attempt to interpret the motivations of actions or causes of social actions by employing the intentions of actors.

Describing sociology, Weber expressed his methodological foundations in sociology (Weber, 1968, 4):

Sociology (in the sense in which this highly ambiguous word is used here) is a science concerning itself with the interpretative understanding of social action and thereby with a casual explanation of its causes and consequences. We shall speak of " action" insofar as the acting individual attaches a subjective meaning to his behavior. -Be it overt or covert, omission or acquiescence. Action is "social" insofar as its subjective meaning takes account of the behavior of others and is thereby oriented in its course.

After Weber's methodological foundations in sociology are explained, it is easy to discuss about Weber's commentary on the rise of Islam. This discussion discusses whether Weber followed his methodological principles in his commentary on the rise of Islam and whether his commentary is factual true or not.

According to Weber, Islam was a religion which emerged at Mecca as a pietistic movement but that in Medine mutated into a secular and military one. Summarizing this development, Weber wrote (Weber, 1968, 444): 
The religion of Muhammad, which is fundamentally political in its orientation and his position in Medine, which was in between that of an Italian (Podesta) and of Calvin of Geneva, grew primarily out of his purely prophetic mission. A merchant, he was first a leader of pietistic bourgeois conventicles in Mecca, until he realized more and more clearly that the ideal external basis for his missionizing would be provided by the organization of the interests of the warrior clans in the acquisition of booty.

Weber described Mohammed as a person who reshaped Islam according to the needs of warriors. In Weber's view, Mohammed realized that if he met the needs of warriors, he would be successful in the spreading of Islam. Thus, he applied to warriors and refashioned Islam in terms of warriors' mundane needs and military interests. Thus, Islam constituted the "psychological dynamism" for warrior clans, and some Islamic beliefs were adapted "almost entirely to the aim of the psychological preparation of the faithful for the battle in order to keep a maximum numbers of combatants for Islam. Such combatants fight not for the sake of Muhammad and Islam, but for the desire for land and power. Hence, the religious war in Islam was essentially for the sake of land and power (Turner, 1974, 34)."

As Turner argued, Weber's account of the origin of Islam is problematic on two points. First, Weber failed to apply his methodical principles that are previously explained in this chapter, and second, there are factual problems in his connecting the religious success to warrior groups (Turner, 1974, 34).

Having ignored the Koranic and the Prophet Mohammed's accounts of early Islam, Weber did not succeed in applying his methodology. If he had applied to his methodology, he must have first given an ear to the voice of Koranic accounts of the early Islamic fight. Instead of him, we can give an ear to the voice of the Qur'an: "But if they (enemy) incline to peace, you also incline to it, and (put your) trust in Allah. Verily, He is the All-Hearer, the All-Knower (The Qur'an, H.1419, 240)." In the verse, the Qur'an stated that Muslims must be ready for peace even in the midst of the fight if there is any inclination towards peace on the other side. There is no merit merely in a fight by itself. It should be a joyful duty not for itself but to establish the reign of peace.

Furthermore, Weber accused early Muslims of being opportunists. However, the Qur'an, which early Muslims believe to be God's book, itself differentiated among the believer, the unbeliever and the hypocrite. The hypocrite can be 
defined as a person who does not accept a purely prophetic mission but enters into Islam for short-term benefits. In this distinction, the Qur'an condemns hypocrites and considers them lower than the unbeliever. Uncovering the intention of hypocrites, the Qur'an says: "Had it been near gain (booty in front of them) and an easy journey, they (hypocrites) would have followed you, but the distance (Tabuk distance) was long for them; and they would swear by Allah "if we only could, we would certainly have come forth with you." They destroy their own selves, and Allah knows that they are liars (The Qur'an, H.1419, 250).”

Weber did not make an attempt to look at Mohammed's statements to grasp his intentions. If, when evaluating Mohammed's intentions, he had looked at Mohammed's statements, he would have understood that he had been hostile to an opportunist commitment to Islam. Having condemned the opportunist and the one who shows off, the Prophet Muhammad said: "Motive determines the value of all conduct, and a person attains that which he desires. The holy Prophet was asked: Which of the three strives in the cause of Allah, one who fights in order that he should display his bravery, or one who fights out of a feeling of indignation, or one who fights in order to show off? He replied: He who fights so that the word of Allah be exalted, is the one who strives in the cause of Allah (Nevevi, 1975, 2-3)." This hadith clearly expressed that the warrior people who fought not for the sake of Allah were not praised but condemned by the Prophet.

In addition, there are factual problems in Weber's connecting the religious success to warrior groups on two points. First, Islam can be accepted as the religion of the city, not of the warriors. Islam originated in the city of Mecca and flourished in the city of Medine (Turner, 1974, 35). When one examined the Qur'an and the Sunnah as the primary and secondary sources of Islam, he realized that these sources were essentially involved in the principles which arrange the city life and civilization. Thus, early Islam causes urban norms to triumph over nomadic ones and the city life over bedouin life (Turner, 1974, 35). Second, early Islam is not a religion of warriors, but of those who defend themselves from enemies. When Weber considered early Muslims worldconquering warriors, he may have not noticed that early Muslims tried to defend themselves against their enemies. When the wars in which early Muslims were involved are examined, it is uncovered that they fought against enemies only in order to defend themselves. For example, in the Hendek (AD. 627) battle, Meccan people decided to get rid of Muslims completely and 
prepared a big army of their period. In this fight, Muslims did not have anything to do except to fight against the army approaching them. Thus, Muslims decided to make a peaceful defense, and they dug ditches around Medina in order to protect themselves from the Meccan army (Watt, 1962, 168). As a result, the war finished without damaging any person's life on both sides. If early Muslims had been warriors, they would have fought against their enemy actively. However, choosing to fight peacefully, Muslims prevented a big war that would have caused many people to die.

According to Turner, having described Islam as a religion of world conquering warriors, Weber accepted a material and determinist perspective in explaining religious success. However, there are some defects in Turner's interpretation of Weber. Because Turner tried to interpret Weber's commentary on Islam in terms of his relation to Marx, he must have been lost in his comparison of Weber with Marx (Fischoff, 1976, 272), and hence, he may have interpreted Weber's commentary in a manner reducing Weber's commentary into Marx's perspective. As it is discussed in this chapter, it is true that Weber failed to apply his methodology, but it is impossible to regard Weber as one who admitted a material and determinist perspective since he believed that social actions could be explained by their relations to religious ideas. If Weber did not accept a material and determinist perspective, and his failure to apply his methodology is true, why did not he succeed in applying his methodology? His failure may be related to the fact that his ideas about Islam were similar with the common nineteen-century misconception about Islam. Furthermore, according to Wolfgang Schluchter, let alone Weber's knowledge about general Islam, his knowledge about primary and secondary sources of Islam even reproduced from secondary literature, the work of German Islamicists of his period, such as Carl Heinrich, Becker and Ignaz Goldziher (Schluchter, 1999, 59).

\section{THE PROTESTANT ETHICS AND THE SPIRIT OF CAPITALISM}

After noticing Weber's commentary on early Islam and his methodology in sociology, it is time to return to Weber's analysis of the relationship between Muslim society and the rise of modern capitalism. Weber examined Islam and Muslim society as he made his thesis about the emergence of modern capitalism. In this sense, he began to examine Islam and tried to address the question: Why did not modern capitalism rise in the Islamic world? 
In order to evaluate Weber's analysis of the relationship between Islamic society and modern capitalism as precisely as possible, it is useful to start with his thesis about the relationship between protestant ethic and the emergence of modern capitalism. It is generally taken as a profound critique of crude materialism, especially of the Marxist thesis of the primacy of base over superstructure (Turner, 1974, 22). Weber argued that there was an elective affinity between modern capitalism and protestant ethic, especially Calvinist ethic.

According to Weber, Calvinist idea of predestination led a set of doctrine to emerge. The doctrine is that "people are predestined to be either among the saved or among the damned. There was nothing that the individual or the religion as a whole could do to affect the fate. (Ritzer, 2008, 150)." This doctrine caused the Calvinists to be anxious about whether they were among the saved. To reduce anxiety, they produced "the idea that sign could be used as indicators of whether a person was saved (Ritzer, 2008, 151)." For Calvinists, the acquisition of wealth become a possible sign of salvation. This belief led Calvinists to engage in intense worldly activity and become a man of vocation as religious duty (Ritzer, 2008, 151).

According to Weber, "the religious valuation of restless, continuos, systematic work in a worldly calling, as the highest means of asceticism, and at the same time the surest and most evident proof of rebirth and genuine faith, must have been the most powerful conceivable lever for the expansion.... of the spirit of capitalism (Weber, 1958, 172)." Thus, Calvinism originated the spirit of capitalism, which fostered modern capitalism.

The concept of God in both Islam and Calvinism is similar. In both Islam and Calvinism, "God is here endowed with [the traits of] absolute unchangeableness, omnipotence and omniscience- that is to say, with an absolutely transcendental character (Schluchter, 1999, 74)." However, the God of Islam is not only one of absolute power but also one of mercy. Describing this fact, Weber wrote: "The ethical concept of salvation is actually alien to Islam. Its God is one of unlimited power but also of mercy and the fulfillment of his commandments is certainly not beyond the powers of humans (Weber, 1968, 623)." This distinction between Islam and Calvinism caused different beliefs of predestination. In Islam, while the absolute powerful God creates evil and goodness, Muslims are responsible for their deeds and salvation and thus, their salvation is dependent on their deeds. 
Nonetheless, in Calvinism, God eternally determined the salvation of some and the damnation of others. Explaining this distinction, Weber wrote: "Islamic predestination knew nothing of the double decree; It did not dare attributed to Allah the predestination of some people to hell, but only attributed to Him the withdrawal of His grace from some people, a belief that admitted man's inadequacy and His inevitable transgression (Weber, 1968, 575).”

However, the empirical consequences of both beliefs of predestination are very similar: the Muslim will struggle to obey the commands of his religion because this is one way to salvation, whereas "the Calvinist will do so because he is enjoined to act as if he were saved. Thus, in both cases the result is active ethical behavior in this world (Peters, 1999, 212).

As it will be discussed in the later chapters, Weber argued that the political, sociological and economic conditions of Islamic societies failed to achieve the prerequisites for the emergence of modern capitalism: "political radicalism, the freedom of cities and the autonomy of rational law (Turner, 1974, 75)."

\section{ISLAMIC PATRIMONIALISM}

In Weber's analysis, the patrimonial structure of traditional Islam was incompatible with the emergence of the capitalism that required "political radicalism, the freedom of cities and the autonomy of rational law (Turner, 1974, 75)."

Weber argued that Islamic societies were not feudal in the European sense. Weber compared Islamic patrimonialism with its Occidental counterpart. He aimed to delineate "that Occidental medieval feudalism constituted a special historical case" that is one of the prerequisites for the emergence and development of modern capitalism (Schluchter, 1999, 94).

There are important distinctions between Islamic patrimonialism and feudalism. While under Islamic patrimonialism, the officials have strict dependence on the ruler, in feudalism, the relationship between ruler and official is not strict as much as in Islamic patrimonialism and, furthermore, the officials are particularly independent from the ruler. Reinhard Bendix has made a useful attempt to summarize the distinction between Islamic patrimonialism and feudalism: "Feudalism is domination by the few who are skilled in war; patrimonialism is domination by one who requires officials for the exercise of his authority. A patrimonial ruler is in some measure dependent upon good will of his subject . .. Patrimonialism appeals to the 
masses against the privileged status group, not the warriors hero but good king the father of his people, are its prevailing ideal (Turner, 1974, 79)."

Weber considers Islamic primarily patrimonial domination "Sultanism." According to Weber: "The feudalization of the economy was facilitated when the Seljuk troops and Memlukes were assigned the tax yield of land and subjects; eventually land was transferred to them as service holdings and they become landowners (Weber, 1968, 1016)." However, these landowners were not independent from the Sultan as in the European feudalism, but they were dependent on the Sultan.

Islamic countries were ruled by a patrimonial bureaucracy. Describing this situation, Weber wrote: "The structure of Islam has been decisively affected by the fact that Mohammed died without male heirs and that his followers did not found the caliphate on hereditary Charisma and indeed during the Umayyad period developed it in outright anti-theocratic manner (Weber, 1968, 1138)."

To summarize our analysis of Weber's remarks on Islamic patrimonialism, we can argue that, for Weber, the patrimonialistic character of Islamic society is one of the important factors, which impedes the emergence of modern capitalism.

\section{ISLAMIC CITY}

For Weber, since Occidental cities have partial autonomy and a free market, they have important prerequisites for the development of modern capitalism. On the contrary, since Islamic cities did not have the partial autonomy, these cities did not have prerequisites for the emergence of modern capitalism. Weber wrote: "The cities of the Arabian coast at the time of Mohammed seem also to have been arrested at the stage, which persisted in the Islamic cities wherever the autonomy of the city and its participate was not, as in the large territorial states, completely destroyed by the monarchy (Weber, 1968, 1231).”

Ibn Khaldun (1332- 1406) noticed the reason why Islamic cities did not have partial autonomy which Weber expressed as a prerequisite for the development of rational capitalism. Ibn Khaldun claimed that Islamic cities did not have their own military forces in order to protect themselves against others, so they had become dependent on the patrimonial ruler and consequently, had lost their autonomy (Hassan, 1982, 293). Their dependence on the ruler hindered the development of capitalist bourgeoisie 
and hence, modern capitalism. Weber expressed this fact in general: "Hence, the more unified the organization of the larger political association, the less was the development of urban political autonomy (Weber, 1968, 1352).”

\section{ISLAMIC LAW}

Weber tried to illustrate the relationship between the economic situation and the forms of law. According to Weber, just as economic situations had important influences on the institutionalization of law through their power on lawmaking, so the nature of law had contributed to the institutionalization of economy (Weber, 1968, 665). In this sense, he wanted to show the relationship between Islamic law (shari'a) and the rise of modern capitalism in Muslim society. Weber presented that Islamic law (shari'a) is one of the hindrances to rationalization and consequently, the emergence of modern capitalism.

It is necessary to explain Weber's analysis of law in order to perceive his analysis of Islamic law. Weber attempted to constitute an evolutionary scheme in which the rational law that prompted the rise of capitalism emerged from the irrational one through four stages (Weber, 1968, 882). Weber's typology of law can be accepted as a typology of lawmakers. Weber made no attempt to provide a static description of types of law but he wanted to show a theoretical account of law development from arbitrary toward rational lawmaking (Turner, 1974, 110). Weber explained this theoretical perspective (Weber, 1968, 882):

From a theoretical point of view, the general development of law and procedure may be viewed as passing through the following stages: first, charismatic legal revelation through "law prophets," second, empirical creation and finding of law by legal honoratiores; law creation through cautelary jurispedance and adherence to precedent; third, imposition of law by secular or theocratic powers; fourth and finally, systematic elaboration of law and professionalized of justice by persons who have received their legal training in a learned and formally logical manner.

This scheme itemizing stages of rational law shows Weber's view about the relationship between the rise of rational capitalism and Occidental law. In his basic view, systematized and rational law played one of the important roles in 
the rise of rational capitalism. The more systematized law, the more favor for the rising of the rational capitalism (Crone, 1999, 252). If capitalism, Weber believed, rests on the stability and predictable economic situation that required rational law, it is hardly surprising that rational law prompted the rise of rational capitalism. Rational law came into being as a result of the separation of profane and sacred law, centralization of law and consequently, systematic training of legal jurists in self-growing universities (Turner, 1974, 110). According to Weber, Islamic law is sacred and has arbitrary features (Weber, 1968, 818). Thus, Islamic law acts as a barrier to the rise of Modern capitalism.

Islamic law has two sources: the Qur'an and the Sunnah. However, in Weber's view, Islamic law is better understood as "the product of the speculative labors" of the jurists on the basis of the Qur'an and the Sunnah. With his definition, Weber brought into focus on the subjective instability of Islamic lawmakers (faqih). These experts formulated Islamic law on the basis of hadith, interpretation of the Qur'an and their own independent judgement. Thus, Weber called Islamic law "jurist law (Weber, 1968, 820)." When Islamic law was delineated by the jurist, the Shari'a seemed to be hold and fixed and perfected and consequently lawmaking was abandoned. Terming this situation "crystallization," Weber wrote: "This crystallization was officially achieved through belief that charismatic juridical -prophetic power of legal interpretation (ijtihad) had been extinguished (Weber, 1968, 819)." For Weber, a gap between legitimization and social reality occurred. In order to close this gap, Weber believed, arbitrary and irrational law appeared.

To summarize up, Weber described Islamic law as a sacred, furthermore, arbitrary and strict law. In his view, these features of Islamic law impeded the rising of rational capitalism.

\section{CONCLUSION}

Our discussion of Weber's observations on Islam has begun with asserting his failure to apply his sociological methodology as he was interpreting early Islam. We have argued that rather than having first been the religion of the warriors, as implied by Weber's writings, early Islam had the characteristics, which had made a progression from Arab tribalism to Islamic civilization. One may add in support of Weber's failure to apply his methodology that not only Koranic and the prophetic accounts of early Islam but also factual trues are contrary to Weber's commentary on early Islam. 
We have also elaborated on Weber's thesis about the relationship between the Protestant Ethics and the Spirit of Capitalism in order to understand his analysis of Islam and the rise of modern capitalism. We have suggested that Islamic predestination, Weber believed, did not impede the rise of modern capitalism, for Islamic predestination also produced the similar results as Calvinism did. In Weber's view, these results prompted the rise of rational capitalism.

In addition, we have tried to examine what hindered the emergence of capitalism in Muslim societies if Islamic ethics had not impeded it. In this point, Weber's commentary on Islamic structure has become crucial. In Weber's view, Islamic patrimonialism, cities and law as a complexity inhibited the development of modern capitalism.

However, these reflections on Weber's commentary on Islam give birth the question, namely, why did Weber's observations on Islam fall roughly under two sections, a commentary on early Islam and an analysis of Islamic patrimonialism. Turner made an attempt to address the question. Weber did not make an attempt to connect these two sections. While his commentaries on early Islam was constructed from the study of seventh-century Islam, Weber's analysis of patrimonialism was constructed from a study of Islamic bureaucracy under the Umayyads and Ottomans (Turner, 1974, 176). This answer also raises a question, namely why was commentary on early Islam factually wrong, whereas his analysis of Islamic patrimonialism was true? As an answer, I shall attempt to put forward the highly speculative claim that Weber's mistakes about early Islam related to his subscription to the common nineteen- century misconception about Islam.

On the other hand, Weber's analysis of Islamic patrimonialism also is not suitable to the example of Turkey. While Turkey has democratic government, autonomous cities and profane and rational law, the rational capitalism has not risen in Turkey. This situation has raised some questions waiting to answer, namely why has not rational capitalism risen in Turkey although it has prerequisites, which, Weber believed, prompt the emergence of modern capitalism? What has impeded the rise of rational capitalism in Turkey? 


\section{BIBLIOGRAPHY}

ALATAS, Syed Hussein. "The Weber Thesis and South East Asia." Achives De Sociologie Des Religions, 8 (Ja-Je 1963): 21-34.

CRONE, Patricia. "Weber, Islamic Law and the Rise of Capitalism," in Max Weber and Islam 2d ed. Toby E. Huff and Wolfgang Schluchter, New Brunswick, N.J.: Transaction, 1999:247-272.

FISCHOFF, Ephraim. Review of Weber and Islam, by Bryan S. Turner. Sociological Analysis 37 (Fall 1976): 272-273.

HUFF, Toby E. and Wolfgang Schluchter. 2d ed. Max Weber and Islam. New Brunswick, N.J.: Transaction, 1999.

HASSAN, Umit. Ibn Haldun Metodu ve Siyaset Teorisi. Ankara: Sevinc Matbaasi, 1982.

IMAM NEVEVI. Gardens of the Righteous. trans. Muhammad Zafrulla Khan. London ; Boston : Routledge \& Kegan Paul, 1974.

THE QUR'AN. trans. Muhammad Taqi-ud-din Al-Hilali and Muhammad Muhsin Khan. Madinah: King Fahd Complex, H.1419.

PETERS, Rudolp. "Paradise or Hell? The Religious Doctrine of Election in Eighteen and Nineteen Century, Islamic Fundamentalism and Protestant Cakvinism," in Max Weber and Islam 2d ed. Toby E. Huff and Wolfgang Schluchter, New Brunswick, N.J. : Transaction, 1999:205-217.

RITZER, George. Sociological Theory. New York: McGraw-Hill Higher Education, 2008.

TURNER, Bryan S. Weber and Islam. London; Boston : Routledge \& Kegan Paul, 1974

WATT, Montgomery W. Muhammed Prophet and Statesman. New York: Oxford University Press, 1962.

WEBER, Max. Economy and Society. trans. Guenther Roth and Claus Wittich. New York: Bedmister, 1968.

-The Protestant Ethics and the Spirit of Capitalism. trans. Talcott Parsons. New York: Scribner, 1958. 